\title{
Особливості діагностики та комплексного лікування артеріовенозних форм вроджених судинних мальформацій кінцівок
}

\author{
Л. М. Чернуха, О. В. Каширова
}

Національний інститут хірургії та трансплантології імені О. О. Шалімова НАМН України, м. Київ

\section{Peculiarities of diagnosis and complex treatment of arterio-venous forms of the inborn vascular malformations of the extremities}

\author{
L. M. Chernukha, O. V. Kashyrova \\ Shalimov National Institute of Surgery and Transplantology, Kyiv
}

\section{Реферат}

Мета. Поліпшення результатів лікування хворих з артеріовенозними формами вроджених судинних мальформацій (АВФ ВСМ) кінцівок на основі розроблення диференційованих алгоритмів діагностики та лікування.

Матеріали і методи. Робота базуеться на даних комплексного клінічного дослідження та результатах хірургічного лікування 155 паціентів з АВФ ВСМ кінцівок. Строки спостереження становили від 1 міс до 10 років. Чоловіків було 65 (42\%), жінок - 90 (58\%), число чоловіків і число жінок співвідносилися як 1: 1,4. Середній вік пацієнтів становив $(25,1 \pm 10,4)$ року. У віці до 18 років (дитяча вікова група) було 53 (34\%) хворих. Клінічний матеріал аналізували в залежності від клінікоанатомічних форм захворювання, які були розподілені на 11 груп на основі робочої класифікаційної схеми «VASC + T». Результати. Розроблення класифікаційної схеми вроджених судинних мальформацій уможливило поліпшення формування плану діагностики та етапного лікування пацієнтів у вигляді алгоритмів у залежності від клініко-анатомічної форми захворювання. Застосування етапного комплексного підходу з використанням емболізаційних, ендовенозних та хірургічних методик дало змогу уникнути розвитку великих післяопераційних ускладнень.

Висновки. Впровадженням розробленої тактики досягнуто задовільних віддалених результатів лікування у 136 (94,4\%) паціентів.

ключові слова: вроджені судинні мальформації; артеріовенозна форма; клініко-анатомічні форми; алгоритми діагностики та лікування.

\section{Abstract}

Objective. Improvement of the treatment results in the patients, suffering arterio-venous inborn vascular malformations (AVIVM) of the extremities, basing on elaboration of differentiated algorithms of diagnosis and treatment.

Materials and methods. The investigation is based on data of complex clinical investigations and results of surgical treatment in 155 patients, suffering AVIVM of the extremities. A follow-up duration have constituted 1 mo - 10 yrs. There were 65 (42\%) men, and 90 (58\%) women, while the men to women ratio - 1: 1.4. Average age of the patients have constituted (25.1 \pm 10.4) yr. There were 53 (34\%) patients, ageing up to 18 yrs old (a pediatric age Group). Clinical material was analyzed, depending on clinic-anatomic forms of the disease. The patients were distributed into 11 Groups, basing on the working classification scheme «VASC $+\mathrm{T}$.

Results. Elaboration of a classification scheme of the inborn vascular malformations made it possible to improve the plan formation for diagnosis and the staged treatment of the patients due to elaborated algorithms, depending on clinic-anatomical form of the disease. Elimination of development of serious postoperative complications was achieved due to application of a staged complex approach, using embolic, endovenous and surgical procedures.

Conclusion. Introduction of the tactics elaborated have resulted in achievement of satisfactory outcomes of treatment in 136 (94.4\%) patients.

Keywords: inborn vascular malformations; arterio-venous form; clinico-anatomical forms; algorithms of diagnosis and treatment.

Вроджені судинні мальформації (ВСМ), або ангіодисплазії - справжні структурні аномалії, які утворюються в період ембріонального васкуло- і ангіогенезу в результаті неповної резорбції первинних кровоносних судин. Загальною гемодинамічною ознакою артеріовенозних форм (АВФ) ВСМ є шунтування артеріальної крові відразу у вени, минаючи капілярну мережу та викликаючи виражені анатомо-функціональні та тяжкі гемодинамічні порушення [1 - 10].

Досі немає повної згоди фахівців у питаннях термінології, не створено єдиної універсальної класифікації даних утворень, яка повністю задовольняла б вимогам судинних і ендоваскулярних хірургів-практиків; не напрацьовано чітких і загальноприйнятих критеріїв їх диференціальної діагностики, в тому числі з новоутвореннями, що призводить до діагностичних і тактичних помилок та досить пізнього звернення пацієнта в спеціалізований судинний центр, коли в нього виявляють вже стадію незворотних порушень і загальну декомпенсацію [8, 11 - 15]. Більш того, лікують ВСМ (ангіодисплазіі) як в Україні, так і за кордоном здебільшого хірурги загального профілю, дитячі хірурги і дерматологи, а ефективність численних застосовуваних 
методик не вивчено. Багато в чому ситуація, що склалася, обумовлена незнанням етіології та патогенезу ВСМ. У літературі мало робіт, в яких проаналізовано ефективність існуючих методів лікування різних клініко-анатомічних форм ВСМ, немає уніфікованої тактики іх застосування у вигляді чітко розроблених стратегій і алгоритмів [8 - 10]. Частота виникнення післяопераційних рецидивів сягає 30 48\%, що обумовлено як об'єктивними (справжня поширеність процесу), так і суб'єктивними (первинна недооцінка обсягу ураження) факторами [1, 8 - 10].

Мета дослідження: поліпшення результатів лікування хворих з АВФ ВСМ кінцівок на основі розроблених диференційованих алгоритмів діагностики та лікування.

\section{Матеріали і методи дослідження}

Робота базується на даних комплексного клінічного дослідження і результатах оперативного лікування 155 пацієнтів з АВФ ВСМ у відділенні хірургії магістральних судин Інституту з 2005 по 2017 р. Чоловіків було 65 (42\%), жінок - 90 (58\%). Число чоловіків і число жінок співвідносилися як 1: 1,4. Переважали пацієнти молодого віку, їх середній вік на момент першої госпіталізації становив $(25,1 \pm 10,4)$ року. У віці до 18 років (дитяча вікова група) було 53 (34\%) пацієнти. Зазначені вікові групи порівнянні за статтю та віком.

Клінічний матеріал аналізували в залежності від клініко-анатомічних форм артеріовенозних мальформацій (ABM). Розподіл пацієнтів на групи здійснювали на підставі розробленої класифікаційної схеми "VASC+T" клініко-анатомічних форм захворювання, що допомагала визначати тактику діагностики та лікування і мала такий вигляд:

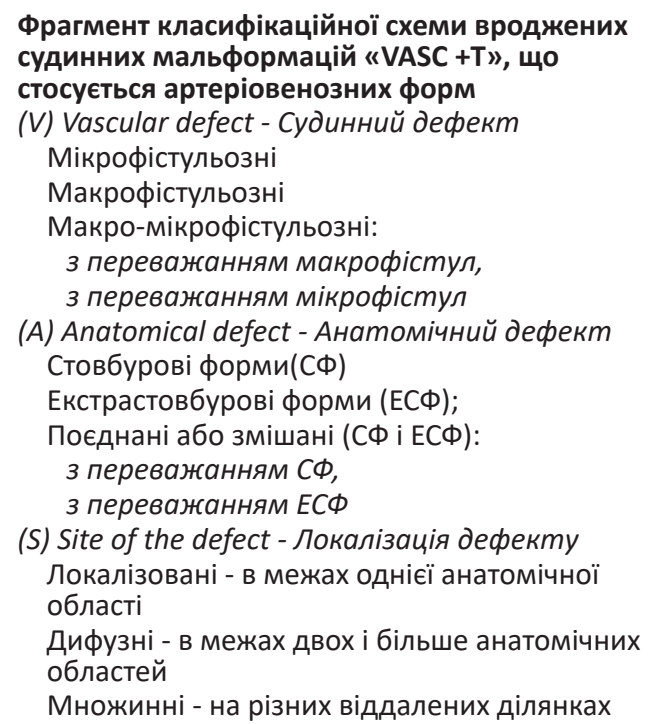

(C) Complications - ускладнення

Хронічна артеріальна недостатність, стадії I-IV (за Фонтейном - Покровським) Хронічна венозна недостатність, клінічний клас 0-VI (CEAP)

Хронічна лімфатична недостатність

Ускладнення, які є показаннями до оперативного втручання

(T) Congenital vascular tumors - Вроджені судинні пухлини

3 урахуванням клініко-анатомічної форми ВСМ (макро-, мікрофістульозні, змішані або комбіновані) і переважного судинного ембріонального компонента (макрофістульозні комбіновані) пацієнти були розподілені на 11 груп (табл. 1). До змішаних (комбінованих) форм віднесені ВСМ з поєднанням венозної вади та одиничних мікрофістул. Пацієнтів з АВФ ВСМ з наявністю мікрофістул було найбільше - 100 (65\%). За поширеністю переважали дифузні форми з ураженням нижніх кінцівок - відповідно 112 (73\%) і 98 (63\%) пацієнтів, а серед пацієнтів з макрофістульозними дифузними АВФ ВСМ найчисленнішою була група III - 12 (46\%) пацієнтів.

Алгоритм обстеження пацієнтів включав: клінічний огляд, кольорове дуплексне ангіосканування (КДАС), ультразвукову доплерографію (УЗДГ), артеріографію, флебографію, мультиспіральну комп'ютерну томографію (МСКТ) з ангіографією, дослідження кісток, загальноклінічні методи (лабораторні дослідження, електрокардіографія, ехокардіографія).

Після клінічного огляду спочатку досліджували регіонарну гемодинаміку за допомогою ультразвукових методів, що уможливило вже на початковому етапі діагностики диференціювати наявність макро- або мікрофістул, потім - системну гемодинаміку, після чого за допомогою інвазивних променевих методів деталізували клініко-анатомічну форму АВМ. У разі виявлення макрофістульозних форм уточнювали переважний ембріональний компонент - СФ чи ЕСФ. Якщо виявляли мікрофістульозні і змішані форми, виконували флебографію, потім - артеріографію (рис. 1).

Функціональний стан артеріальної та венозної гемодинаміки вивчали на різних етапах лікування пацієнтів з метою контролю та планування наступного етапу.

\section{Результати}

Вивчення порушень гемодинаміки показало наявність виражених проявів хронічної венозної гіпертензії і судинно-кісткового синдрому у пацієнтів з дифузними мікрофістульозними і змішаними (комбінованими) АВФ ВСМ - відповідно 88 (56,8\%) та 56 (36\%) спостережень, а також більш вираже-

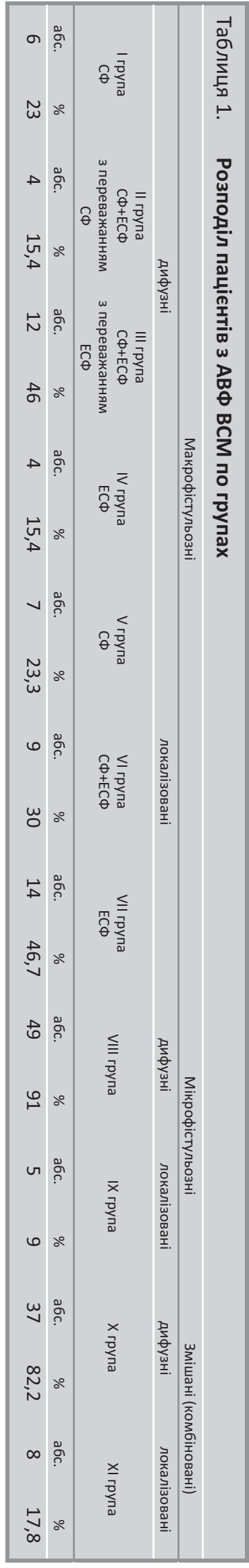




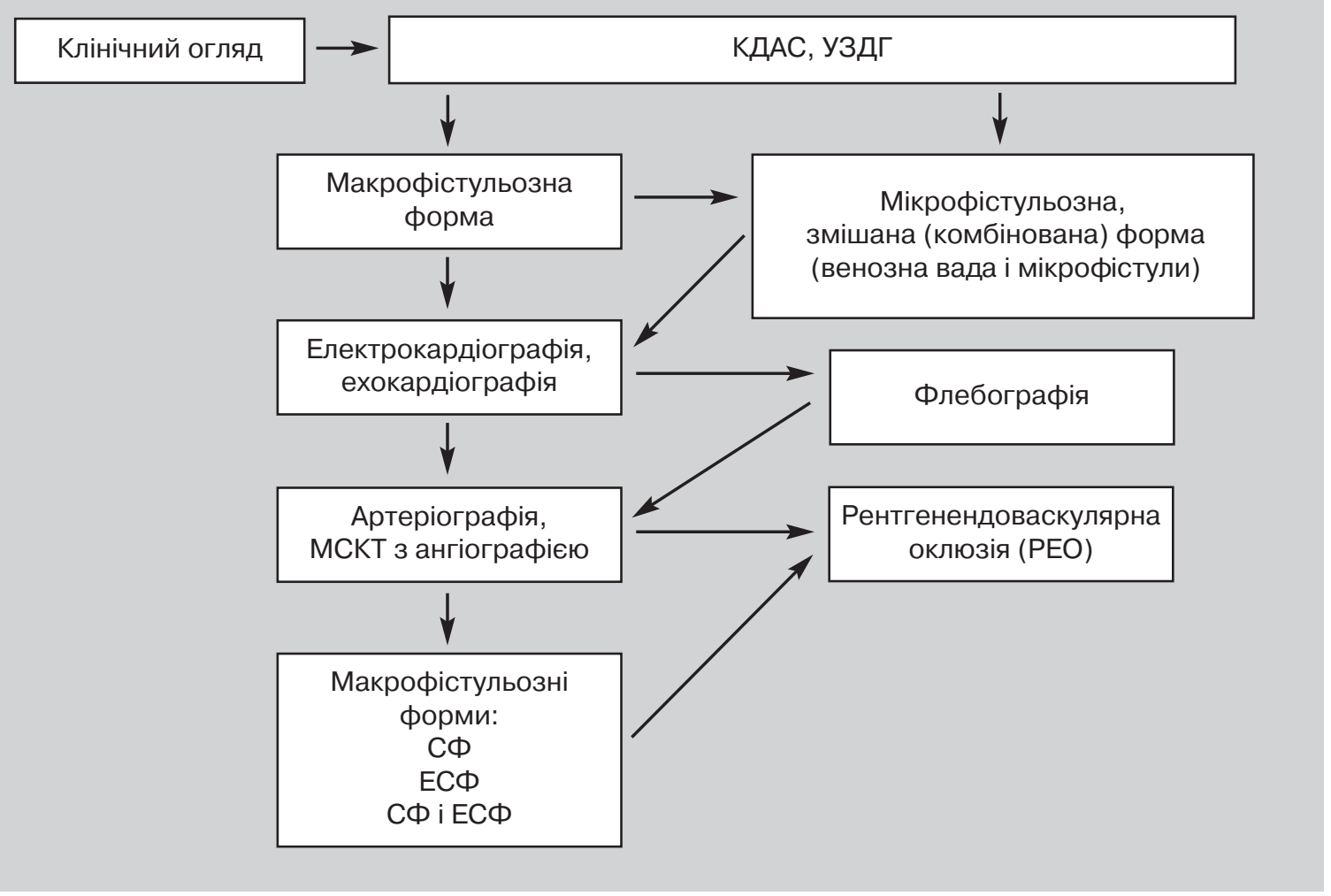

Puc. 1 .

Алгорити лікувально-діагностичних заходів при АВФ ВСМ.

них проявів хронічної артеріальної і серцевої недостатності у пацієнтів з дифузними макрофістульозними АВФ ВСМ - відповідно 26 (17\%) та 25 (16\%) спостережень, що дало змогу оптимізувати індивідуальний диференційований підхід до діагностики і лікування в залежності від клініко-анатомічних форм захворювання.

Плануючи оперативне втручання, наявність двох і більше відносних показань до лікування прирівнювали до одного асболютного показання. Помірний больовий синдром вважали відносним показанням, виражений больовий синдром - абсолютним показанням (табл.2).
Стратегія лікування АВФ ВСМ була такою:

індивідуальний етапний підхід з урахуванням клініко-анатомічної форми АВМ, який полягав у використанні ендоваскулярних методик у поєднанні з хірургічними і мініінвазивними методиками (емболізаційними, ендовенозними), що уможливило підвищення радикальності за мінімальної інвазивності - 362 (100\%) спостереження; корекція артеріовенозного (AВ) шунтування, магістралізація кровотоку в судинному сегменті - 234 (64,6\%) спостереження: скелетизація судин з інтраопераційною емболізацією, резекція і протезування за наявності артеріаль-

\begin{tabular}{|c|c|c|}
\hline \multirow{2}{*}{ Показання } & \multicolumn{2}{|c|}{ Число хворих } \\
\hline & абс. & $\%$ \\
\hline \multicolumn{3}{|l|}{ Абсолютні показання } \\
\hline виражений больовий синдром & 9 & 5,8 \\
\hline кровотеча & 16 & 10,3 \\
\hline прогресуюча хронічна серцева недостатність & 4 & 2,6 \\
\hline трофічні виразки & 26 & 16,8 \\
\hline високий ризик розриву артеріальних (венозних) аневризм & 5 & 3,2 \\
\hline ураження, локалізоване у загрожуючих життю або кінцівці областях & 1 & 0,6 \\
\hline \multicolumn{3}{|l|}{ Відносні показання } \\
\hline функціональна недієздатність або ураження що порушує щоденну активність і якість життя & 14 & 9 \\
\hline помірний больовий синдром & 30 & 19,4 \\
\hline $\begin{array}{l}\text { судинно-кістковий синдром з швидким прогресуванням невідповідності зростання кістки в довжину } \\
\text { із значним викривленням таза або компенсаторним сколіозом }\end{array}$ & 65 & 41,9 \\
\hline $\begin{array}{l}\text { косметичний дефект, який супроводжується фізичною та психологічною недієздатністю з } \\
\text { вираженим негативним впливом на якість життя (в тому числі «варикозний симптомокомплекс») }\end{array}$ & 116 & 74,8 \\
\hline ураження з рецидивуючою інфекцією (місцевий або системний сепсис) & 4 & 2,6 \\
\hline ураження з персистуючою лімфореєю & 1 & 0,6 \\
\hline
\end{tabular}




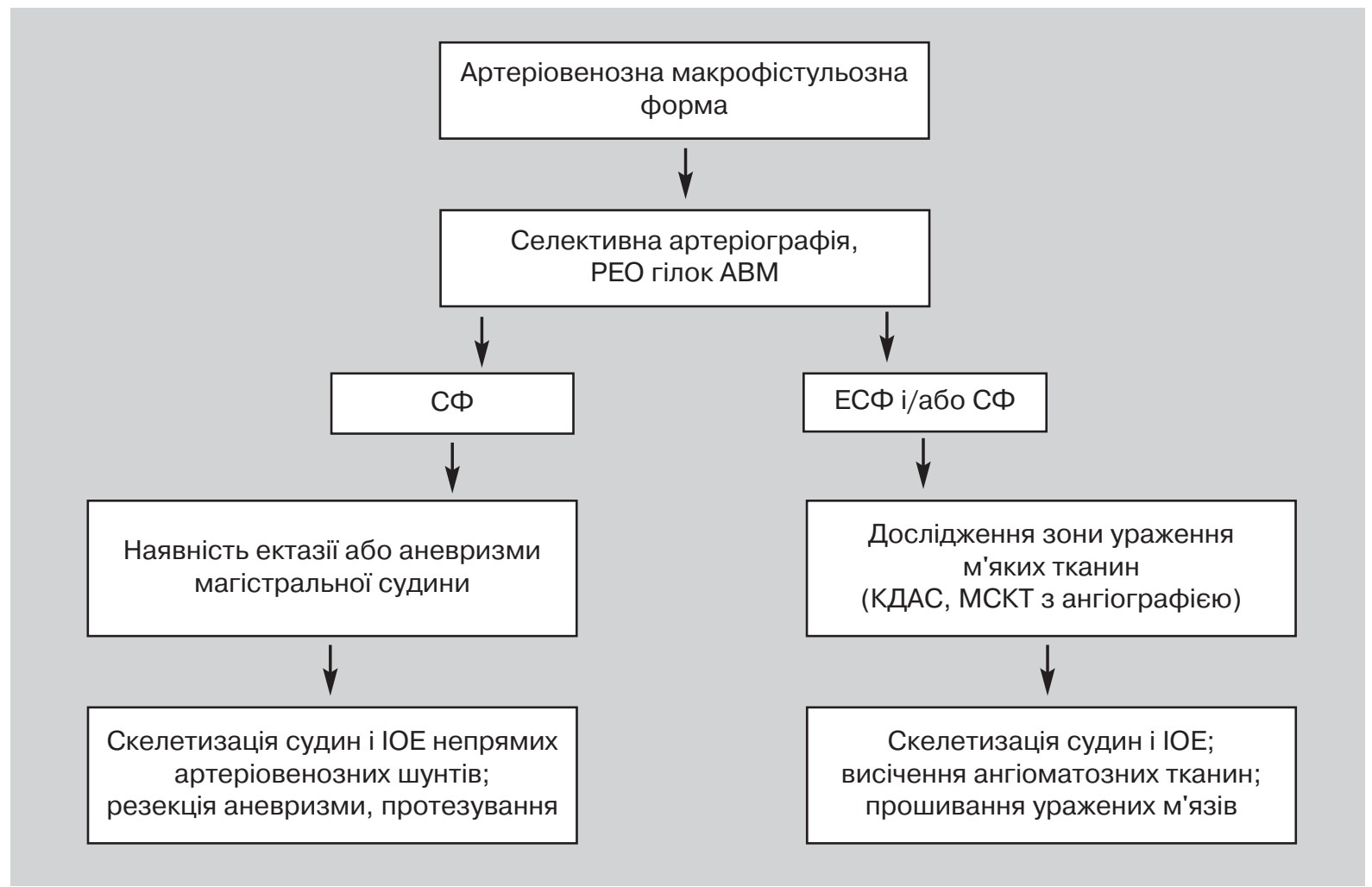

Puc.2.

Алгорити діагностики та лікування макрофістульозних АВФ ВСМ.

них аневризм при СФ; висічення ангіоматозних тканин, прошивання м'язів при ЕСФ; інтраопераційна емболізація (IOE) артеріовенозних гілок, ампутація - $5(1,4 \%)$ спостережень, реампутація - 2 (0,6\%) спостереження;

корекція венозної гіпертензії у глибокій і/або поверхневій венозній системі - 111 (30,7\%) спостережень: у глибокій венозній системі виконували резекцію, протезування або пластику аневризм, резекцію задніх великогомілкових вен, профундизацію підшкірної венозної магістралі 11 (3\%) спостережень, у поверхневій венозній системі здійснювали корегуючу флебектомію в поєднанні з ендоваскулярними, ендовенозними та емболізаційними методиками і еластичною компресією - 100 (27,6\%) спостережень;

усунення косметичних дефектів - 17 (4,7\%) спостережень: пластичні етапи в поєднанні з емболізаційними методиками і склеротерапією.

3 метою оптимізації діагностичних та лікувальних заходів у залежності від клініко-анатомічних та ембріональних характеристик АВФ ВСМ були розроблені та впроваджені відповідні алгоритми. Щодо макрофістульозних АВФ ВСМ основний акцент був зроблений на диференціальну діагностику СФ та ЕСФ, тому що саме переважання ембріонального компонента визначає тип оперативного втручання (рис. 2). Варто зазначити, що більшість макрофістульозних форм є поєднаними (СФ і ЕСФ).

Після інвазивних діагностичних і лікувально-діагностичних методик початковим етапом виконували комплексну хірургічну корекцію артеріовенозного шунтування 3 подальшою корекцією венозної гіпертензії в глибокій венозній системі, потім - у поверхневій венозній системі шляхом використання комплексного підходу (рис.3).

\section{Обговорення}

Застосування етапного комплексного підходу дало змогу уникнути розвитку великих післяопераційних ускладнень. Некроз шкіри, м'яких тканин ампутаційної кукси спостерігали у 2,1\% пацієнтів, парестезії, набряк зовнішніх статевих органів, тромбоз аневризми підколінної вени - у 0,7\% пацієнтів.

У післяопераційному періоді пацієнтам з АВФ ВСМ рекомендували обмеження фізичних і статичних навантажень на кінцівки, з метою корекції гемодинаміки і хронічної венозної гіпертензії - носіння еластичного трикотажу III ступеня компресії.

Строки спостереження становили від 1 міс до 10 років. Безпосередні результати лікування оцінювали в строки до 6 міс, віддалені - 6 міс і більше, в середньому до 2 років. Для оцінки результату лікування використана система, в основу якої покладено клінічні дані і дані КДАС. Результат лікування всіх АВФ ВСМ був переважно задовільний, про що свідчили зникнення больового синдрому, зменшення набряку, поліпшення показників гемодинаміки за даними КДАС.

Безпосередні і віддалені результати лікування локалізованих форм були однаковими, що пов'язано з можливістю їх радикального лікування. Переважав задовільний результат лікування всіх цих форм, найчастіше його відмічали у пацієнтів з макрофістульозними формами - 25 $(17,4 \%)$. У 3 (2,1\%) пацієнтів з такими ж формами ВСМ отримали хороший результат. Незадовільних результатів не спостерігали.

У всіх групах пацієнтів з дифузними АВМ отримали переважно задовільні безпосередні і віддалені результа- 


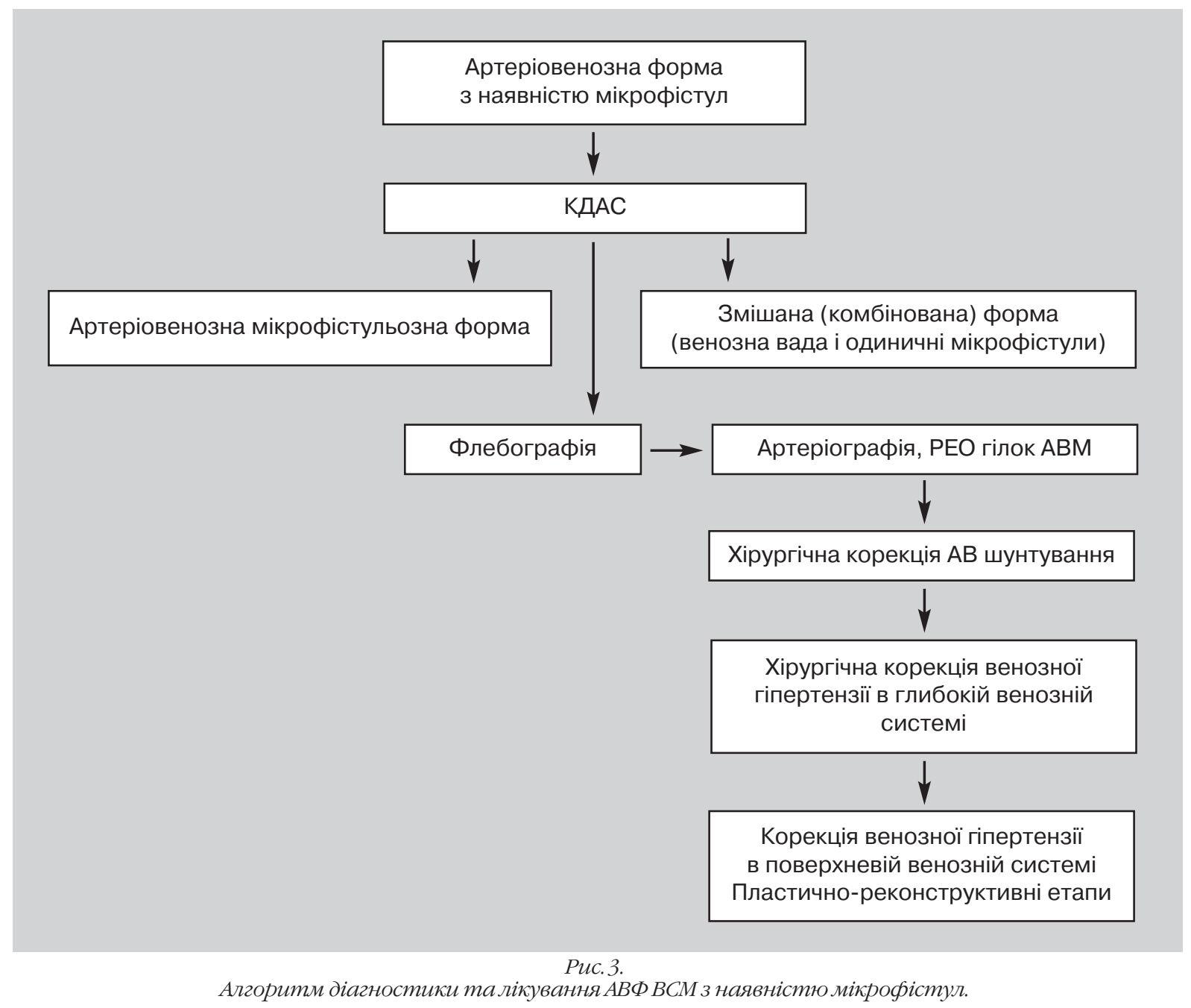

ти лікування, зокрема, у 136 (94,4\%) пацієнтів з мікрофістульозними і поєднаними формами. Незадовільний результат спостерігали у 1 (0,7\%) пацієнта з гемодинамічно тяжкою макрофістульозною формою. У віддаленому періоді число таких пацієнтів з незадовільними результатами збільшилось до 5 (3,5\%), що насамперед пов'язано з особливостями гемодинаміки і вираженою проліферативною активністю АВМ з переважанням екстрастовбурового компонента.

У сучасній літературі повідомлення про поєднаний (ендоваскулярний та хірургічний) або комбінований спосіб лікування АВФ ВСМ нечисленні [8 - 10, 12, 15]. Пацієнтів з дифузними, особливо макрофістульозними АВФ ВСМ, багато дослідників вважають неоперабельними. Як єдиний метод лікування таких пацієнтів після кількох спроб ендоваскулярних етапів з метою порятунку життя пропонують ампутацію кінцівки на тлі тяжкої рецидивуючої кровотечі і швидко прогресуючої серцевої недостатності $[1,3,9,10,12]$. Відомі поодинокі дослідження в основному стосуються клінічних спостережень форм ВСM, які частіше виявляють, а саме: венозних BCM, локалізованих АВМ шиї, головного мозку, АВМ важкодоступних анатомічних областей і поверхневих BCM $[4,5,8,10,14,15]$. Так, за даними A. Guillet і співавторів
[8], хвороба прогресувала у 74\% пацієнтів з поверхневими (капілярними) дистальними АВМ кінцівок (період спостереження - 57,6 міс), тоді як у нашому дослідженні прогресування хвороби у віддаленому періоді відбулося у 8 (5,5\%) пацієнтів 3 дифузними макрофістульозними АВФ ВСМ; частота дистальних ампутацій становила 37\%, в нашому дослідженні - 2,7\%: економну ампутацію при локалізованій формі захворювання (дистальний відділ кінцівки, резекція стопи, ампутація пальця) виконали 3 (1,6\%), реампутацію кінцівки - 2 (1,1\%) пацієнтам; збереження симптомів і подальше прогресування хвороби спостерігали у 42\% пацієнтів, у нашому дослідженні - у 14 (26,4\%) пацієнтів груп I - IV. Що стосується отриманих результатів лікування пацієнтів 3 дифузними макрофістульозними і змішаними формами АВМ з наявністю вад розвитку глибокої венозної системи (групи X, XI), то порівняння їх з даними інших авторів виявилося неможливим, оскільки більшість дослідників (B. B. Lee, J. B. Mulliken, V. Triponis) вважають таких пацієнтів неоперабельними.

B. B. Lee [10] поділився досвідом лікування 90 (62\%) 3 145 пацієнтів з ВСМ. Переважно дифузну ЕСФ ураження мали 82 пацієнти, СФ з наявністю макрофістул - 2. Iз 90 пацієнтів з АВМ тільки 21 визнаний «хірургічно 
доступним». У 20 пацієнтів застосували поєднане ендоваскулярне лікування (27 різних комбінацій) і подальше хірургічне висічення ангіоматозних тканин, 1 пацієнту виконали хірургічне висічення. Результати лікування протягом 41 міс спостереження оцінені як хороші. У 69 (47,6\%) «хірургічно неуспішних» пацієнтів з АВФ ВСМ виконано 332 ендоваскулярних втручання 3 хорошим проміжним результатом, рецидив виник у 9 (13\%) із 69 пацієнтів після лікування важкодоступних АВФ BCM. Для порівняння: ми спостерігали прогресування захворювання у віддаленому періоді у 8 (5,55\%) пацієнтів груп I - IV після лікування «хірургічно неуспішних» дифузних макрофістульозних АВМ і у 3 (2,1\%) пацієнтів груп V - VII з локалізованими макрофістульозними формами. У рамках комплексного індивідуального підходу до лікування АВФ ВСМ вважаємо більш прийнятним щодо дифузних АВФ ВСМ використовувати термін «прогресування захворювання», а щодо локалізованих - «рецидив».

Таким чином, стратегії лікування, розроблені на основі індивідуального диференційованого підходу в залежності від клініко-анатомічних форм ВСМ, дають змогу отримати результати, порівнянні з результатами, отриманими іншими авторами. Невисокі показники незадовільних результатів лікування свідчать про ефективність розроблених підходів.

\section{Висновки}

1. Розроблені алгоритми діагностики та лікування АВФ ВСМ забезпечують диференційований індивідуальний підхід до лікування таких пацієнтів з урахуванням клініко-анатомічних форм захворювання, що включає поєднане використання емболізаційних, ендовенозних та хірургічних методик.

2. Хороші віддалені результати лікування отримані тільки у 3 (2,1\%) пацієнтів з локалізованими макрофістульозними формами, задовільні - у 136 (94,4\%), незадовільні - у 5 (3,5\%) пацієнтів з дифузними макрофістульозними АВФ BCM, що перш за все пов'язано з особливостями гемодинаміки і вираженою проліферативною активністю АВМ з наявністю екстрастовбурового компонента.

\section{Підтвердження \\ Фінансування}

Ця робота є фрагментом планової НДР. Фінансування за рахунок держбюджеу.

\section{Внесок авторів}

Л. М. Чернуха - концепсія та дизайн дослідження, збирання та обробка матеріалу; О. В. Каширова - аналіз отриманих даних, написання тексту, збирання та обробка матеріалу.

Всі автори прочитали та схвалили остаточний варіант рукопису.

\section{Конфлікт інтересів}

Автори декларують відсутність конфлікту інтересів.

Згода на публікацію

Всі автори дали згоду на публікацію цього рукопису.

\section{References}

1. Chernikha L, Kashyrova O, Vlaykov G, Guch A, Vlasenko O, Kondratyuk $\mathrm{V}$. The main aspects of diagnostics and treatment of diffuse arteriovenous forms of congenital vascular malformations of extremities with the presence of microfistulas. Acta Phlebologica 2018 Aug;19(2):49 55. doi: 10.23736/S1593-232X.18.00418-6

2. Banzic I, Brankovic M, Maksimović Ž, Davidović L, Marković M, Rančić Z. Parkes Weber syndrome-Diagnostic and management paradigms: A systematic review. Phlebology. 2017 Jul;32(6):371-383. doi: $10.1177 / 0268355516664212$.

3. Boon LM1, Ballieux F, Vikkula M. Pathogenesis of vascular anomalies. Clin Plast Surg. 2011 Jan;38(1):7-19. doi: 10.1016/j.cps.2010.08.012.

4. Mulligan PR, Prajapati HJ, Martin LG, Patel TH. Vascular anomalies: classification, imaging characteristics and implications for interventional radiology treatment approaches. Br J Radiol. 2014 Mar;87(1035):20130392. doi: 10.1259/bjr.20130392.

5. Cox JA, Bartlett E, Lee EI. Vascular malformations: a review. Semin Plast Surg. 2014 May;28(2):58-63. doi: 10.1055/s-0034-1376263.

6. Duffy K. Genetics and syndromes associated with vascular malformations. Pediatr Clin North Am. 2010 Oct;57(5):1111-20. doi: 10.1016/j. pcl.2010.07.001.

7. Revencu N, Boon LM, Mendola A, Cordisco MR, Dubois J, Clapuyt P, et al. RASA1 mutations and associated phenotypes in 68 families with capillary malformation-arteriovenous malformation. Hum Mutat. 2013 Dec;34(12):1632-41. doi: 10.1002/humu.22431.

8. Guillet A, Connault J, Perrot P, Perret C, Herbreteau D, Berton M, et al. Early symptoms and long-term clinical outcomes of distal limb's cutaneous arterio-venous malformations: a retrospective multicentre study of 19 adult patients. J Eur Acad Dermatol Venereol. 2016 Jan;30(1):3640. doi: $10.1111 /$ jdv.12961.

9. Madani H, Farrant J, Chhaya N, Anwar I, Marmery H, Platts A, et. al. Peripheral limb vascular malformations: an update of appropriate imaging and treatment options of a challenging condition. Br J Radiol. 2015 Mar;88(1047):20140406. doi: 10.1259/bjr.20140406.

10. Lee BB. Changing Concept on Vascular Malformation: No Longer Enigma. Ann. Vasc. Dis. 2008; 1(1): 11-9. doi 10.3400/avd.AVDsc00207

11. Garzon MC, Weitz N, Powell J. Vascular anomalies: differential diagnosis and mimickers. Semin Cutan Med Surg. 2016 Sep;35(3):170-6. doi: $10.12788 /$ j.sder.2016.052.

12. Nosher JL, Murillo PG, Liszewski M, Gendel V, Gribbin CE. Vascular anomalies: A pictorial review of nomenclature, diagnosis and treatment. World J Radiol. 2014 Sep 28;6(9):677-92. doi: 10.4329/wjr.v6.i9.677.

13. Yakes WF. Yakes' AVM classification system. Journal of Vascular and Interventional Radioigy. [Internet]. 20152017 [cited 2019 Jan 10]; 26(2, Suppl):S224. Available from: https://www.jvir.org/article/S10510443(14)01833-8/abstract. doi: 10.1016/j.jvir.2014.12.596

14. Kapadia SR, Thakore VM, Patel HM. Vascular malformations: An update on classification, clinical features, and management principles. Indian J Vasc Endovasc Surg [serial online] 2017 [cited 2019 Jan 10];4:152-62. Available from: http://www.indjvascsurg.org/text. asp?2017/4/4/152/217457. doi:10.4103/ijves.ijves_57_17.

15. Lee BB, Antignani PL, Baraldini V, Baumgartner I, Berlien P, Blei $\mathrm{F}$, et al. ISVI-IUA consensus document diagnostic guidelines of vascular anomalies: vascular malformations and hemangiomas. Int Angiol.; 2015; Aug; 34(4): p. 333-74. PMID: 25284469.aa

Отримана 18.08.2018 